\title{
KEWENANGAN MAHKAMAH AGUNG DALAM PEMBENTUKAN \\ DAN PEMBINAAN PENGADILAN MILITER PERTEMPURAN DI INDONESIA
}

\author{
Raditya F. Rifandhana \\ Fakultas Hukum Universitas Merdeka \\ Jl. Jl. Terusan Raya Dieng 62-64 Malang \\ Email: adietz_008@yahoo.com
}

\begin{abstract}
Journal writing is about The Authority of the Supreme Court stated Article 24, Paragraph 2, the Authority may become Implementation Authority of the Court in the Establishment and Development of the Military Court of Justice Battle.Establishment and Development in Military Courts environment conducted by the Authority of the Supreme Court, the Establishment and Development consists of:

a. Establishment of Organization and Development of the High Military Court of Army personnel

b. Establishment of Organization and Development of Army personnel Main Military Courts

c. Establishment of Organization and Development of the Military Court Battle

Methods used method of empirical research regarding the judicial authority of the Supreme Court in the Establishment and Development of Military Court Battle in Indonesia.

Method an empirical approach used juridical system regarding the formation and development of military court battles conducted by the authority of the Supreme Court in cooperation with TNI Commander with a Joint Decree of the Chairman of the Supreme Court of the Republic of Indonesia and the TNI Commander Number: KMA / 065A / SKB / IX / 2004 Number: Skep / 420 / IX / 2004 on Cooperation in Development Coaching Personnel Military For Army personnel on duty at the Court in Environmental Military Court, the include: a. Establishment of Organization and Development of High Military Court of Army personnel b. Establishment of Organization and Development of Army personnel Main Military Court c. Establishment of Organization and Development of Military Court Battle Army personnel. Discussion and results regarding the authority of the Supreme Court stated in Article 24, Paragraph 2, the Authority can be Implementation Authority of the Court in the Establishment and Development of Military Court Battle.
\end{abstract}

Key words: authority of the supreme court, law effectiveness, organizational formation and development of army personnel in the military courts, a joint decree, military justice

\footnotetext{
Abstrak

Penulisan Jurnal ini membahas Kewenangan Mahkamah Agung yang tertera Pasal 24 Ayat 2 Kewenangan tersebut menjadi Pelaksanaan Kewenangan Mahkamah Dalam Pembentukan Dan Pembinaan Pengadilan Militer Pertempuran.Pembentukan dan Pembinaan Peradilan dalam lingkungan Pengadilan Militer dilakukan oleh Kewenangan Mahkamah Agung RI maka Pembentukan dan Pembinaan tersebut terdiri dari:
} 
a. Pembentukan Organisasi dan Pembinaan Prajurit TNI Pengadilan Militer Tinggi

b. Pembentukan Organisasi dan Pembinaan Prajurit TNI Pengadilan Militer Utama

c. Pembentukan Organisasi dan Pembinaan Pengadilan Militer Pertempuran

Metode Penelitian digunakan metode penelitian empiris yuridis yang mengenai Kewenangan Mahkamah Agung Dalam Pembentukan dan Pembinaan Pengadilan Militer Pertempuran di Indonesia.Metode Pendekatan digunakan empiris yuridis. Pembentukan dan pembinaan pengadilan militer pertempuran dilakukan oleh kewenangan mahkamah agung yang bekerja sama dengan panglima TNI dengan suatu Surat Keputusan Bersama Ketua Mahkamah Agung Republik Indonesia Dan Panglima TNI Nomor: KMA/065A/SKB/IX/2004 Nomor: Skep/420/ IX/2004 Tentang Kerja Sama Dalam Pembinaan Personel Militer Bagi Prajurit TNI Yang Bertugas Pada Pengadilan Dalam Lingkungan Pengadilan Militer, tujuan meliputi:

a. Pembentukan Organisasi dan Pembinaan Prajurit TNI Pengadilan Militer Tinggi

b. Pembentukan Organisasi dan Pembinaan Prajurit TNI Pengadilan Militer Utama

c. Pembentukan Organisasi dan Pembinaan Prajurit TNI Pengadilan Militer Pertempuran.

Pembahasan dan Hasil Kewenangan Mahkamah Agung tertera pada Pasal 24 Ayat 2 Kewenangan tersebut dapat menjadi Pelaksanaan Kewenangan Mahkamah Dalam Pembentukan Dan Pembinaan Pengadilan Militer Pertempuran.

Kata kunci: mahkamah agung, efektifitas hukum, peradilan militer

\section{Latar Belakang}

Indonesia adalah negara hukum yang berdasarkan pada Pancasila dan UndangUndang Dasar Negara Republik Indonesia 1945 (adalah selanjutnya disebut UUDNRI Tahun 1945). Negara Hukum dapat diartikan menjadi Negara yang Penyelenggaraan Kekuasaan Pemerintahannya didasarkan pada hukum. Negara Hukum bertujuan membentuk suatu pemerintah negara indonesia yang melindungi segenap bangsa indonesia dan seluruh tumpah darah Indonesia dan untuk memajukan kesejahteraan umum serta kedaulatan berada di tangan rakyat.Pengertian negara hukum menurutUUDNRI 1945 terdapat di dalam Pasal 1Ayat 2,Ayat3 yang menetapkan bahwa:

Pasal 1 Ayat
(2) "Kedaulatan berada ditangan rakyat dan dilaksanakan menurut Undang-Undang Dasar"

Pasal 1 Ayat

(3) "Negara Indonesia adalah Negara Hukum" Pasal18Undang-UndangNo48Tahun2009 tentang Kekuasaan Kehakiman (LN RI Tahun 2009 No 157) menyatakan bahwa "Kekuasaan Kehakiman adalah kekuasaan kehakiman yang dilakukan oleh sebuah Mahkamah Agung dan badan peradilan yang berada di bawahnya dalam lingkungan peradilan umum lingkungan peradilan agama,lingkungan peradilan militer,lingkungan peradilan tata usaha negara,dan oleh sebuah Mahkamah Konstitusi.Dengan demikian Pengadilan/ Peradilan Militer berada dibawah wewenang Mahkamah Agung,sejajar dengan Peradilan 
Umum,Peradilan Agama dan Peradilan Tata Usaha Negara.Kompetensi menurut Kamus Besar Bahasa Indonesia adalah Kewenangan (kekuasaan) untuk melakukan sesuatu ${ }^{1}$. Kompetensi suatu pengadilan adalah untuk memeriksa,mengadili dan memutus suatu perkara berkaitan dengan jenis dan tingkatan pengadilan yang ada berdasarkan peraturan perundang-undangan yang berlaku.Diketahui bahwa berdasarkan jenis dan lingkungan pengadilan,dan dibedakan atas Pengadilan Umum,Pengadilan Militer,Pengadilan Agama,dan Pengadilan Tata Usaha Negara. Cara untuk mengetahui kompetensi dari pengadilan untuk memeriksa dari suatu pengadilan untuk memeriksa, mengadili dan memutus perkara:

1. Pokok sengketa

2. Melakukan pembedaan atas atribusi dan delegasi

3. Kompetensi absolute dan kompetensi relatif

Pokok sengketanya terletak dalam lapangan hukum privat,maka sudah tentu yang berkompetensi adalah hakim biasa (Hakim Pengadilan Umum).Pokok sengketanya terletak dalam lapangan hukum publik, tentu yang berkompetensi adalah administrasi negara yang berkuasa (Hakim PTUN). Pembagian kompetensi atas atribusi dan delegasi menurut Sjharah Basah, yaitu:

a. Atribusi berkaitan dengan pemberian wewenang yang bersifat bulat (absolute) mengenai materi yang dapat dibedakan:

1. Secara horizontal yaitu wewenang yang bersifat bulat dan melekat dari suatu jenis pengadilan lainnya, yang mempunyai suatu kedudukan sederajat/setingkat.

Contoh:

Pengadilan Administrasi terhadap Pengadilan Negeri (Umum), Pengadilan Agama atau Pengadilan Militer

2. Secara Vertikal yaitu wewenang yang sifat bulat dan melekat dari suatu jenis pengadilan terhadap jenis pengadilan lainnya yang secara berjenjang atau hirarkis mempunyai kedudukan lebih tinggi. Contoh: Pengadilan Negeri (Umum) terhadap Pengadilan Tinggi dan Mahkamah Agung.

B. Delegasi berkaitan dengan pemberian wewenang yang bersifat terinci (relative) di antara badan-badan yang sejenis mengenai wilayah hokum. Contoh: Pengadilan Negeri Bandung dengan Pengadilan Negeri Garut.

Terdapat beberapa kewenangan Pengadilan/Peradilan, di Indonesia mengenal 4(empat) lingkungan Peradilan yakni: Peradilan Umum, Peradilan Agama, Peradilan Militer dan Peradilan Tata Usaha Negara.

1. Kompetensi Absolut Peradilan Umum adalah memeriksa,mengadili dan memutuskan perkara pidana yang dilakukan orang sipil dan perkara perdata,

1 Fuad Hassan, Pengertian Kewenangan, Balai Pustaka, Jakarta, 1999, hlm. 1128. 
kecuali suatu peraturan perundangundang ketentuan lain (Pasal 50 UU No 02 Tahun 1999)

2. Kompetensi Absolut Peradilan Agama adalah memeriksa,mengadili dan memutuskan perkara-perkara orang yang beragama islam dalam bidang perkawinan, warisan, wasiat, hibah, waqaf, dan shadaqah.

3. Kompetensi Absolut Peradilan Tata Usaha Negara adalah memeriksa, mengadili,dan memutuskan sengket yang timbul dalam bidang tata usaha negara antara seseorang atau badan hukum perdata dengan badan atau pejabat tata usaha negara akibat dikeluarkannya suatu keputusan tata usaha negara,termasuk sengketa kepegawaian (Pasal 1 ayat 4 UU 09 Tahun 2004 tentang PTUN).

Adapun Peradilan Militer memiliki kewenangan absolute dan relatif sebagai berikut:

a. Kewenangan Absolut Pengadilan/ Peradilan Militer adalah memeriksa, serta memutus perkara pidana yang dimana perkara tersebut yang menjadi terdakwanya adalah Prajurit TNI.

b. Kewenangan Relatif Pengadilan/ Peradilan Militer adalah terdapat di Pasal 9 ayat 1 Undang-Undang No 31 Tahun 1997 sebagai berikut:

1. Mengadili tindak pidana yang dilakukan oleh seseorang yang pada waktu melakukan tindak pidana adalah: a. yang berdasarkan undang-undang dipersamakan dengan prajurit dikarenakan untuk diberlakukan ayat 1 hurufb UUN Nomor 31 Tahun 1997 orang yang dipersamakan dengan prajurit harus diatur dengan undang-undang

b. anggota suatu golongan atau jawatan atau badan atau yang dipersamakan atau dianggap sebagai Prajurit berdasarkan u n d a n g - u n d a n g. Un t u k diberlakukannya Undang-undang peradilan militer terhadap anggota dimaksud masih diperlukan undang-undang lagi maka dikatakan sebagai kewenangan relative dari peradilan militer

c. seseorang yang tidak masuk golongan pada pasal 1 huruf a,b,c UU No 31 tahun 1997 tetapi atas keputusan panglima dengan persetujuan Menteri Kehakiman harus diadili oleh suatu Pengadilan dalam lingkungan peradilan militer.

d. Memeriksa,memutus dan menyelesaikan sengketa Tata Usaha Angkatan Bersenjata dikarenakan untuk diberlakukan Pasal 9 ayat 2 UU No 31 Tahun 1997 penerapannya masih diperlukan dengan Peraturan Pemerintah 
e. Menggabungkan perkara gugatan ganti rugi dalam perkara pidana yang bersangkutan atas permintaan dari pihak yang dirugikan sebagai akibat yang ditimbulkan oleh tindak pidana yang menjadi dasar dakwaan dan sekaligus memutus kedua perkara tersebut dalam suatu putusan.

Adapun Wewenang dan Tugas dari masing-masing Peradilan Militer yang tertera dalam UU No 31 Tahun 1997 tentang Peradilan Militer sebagai berikut:

Pasal 9 Ayat 1 dan 2Undang-undang No 31 tahun 1997 (Lembaran Negara Republik Indonesia Nomor 3713)Pengadilan Militer bertugas dan berwenang sebagai berikut:

1. Mengadili tindak pidana yang dilakukan oleh seseorang yang pada waktu melakukan tindak pidana adalah Prajurit TNI.

2. Memeriksa, memutus dan menyelesaikan sengketa Tata Usaha Angkatan Bersenjata.

Pasal 41 ayat1 dan 2 Undang-undang No 31 tahun 1997 (Lembaran Negara Republik Indonesia Nomor 3713).Pengadilan Militer Tinggi bertugas dan wewenang sebagai berikut:

1. Pengadilan Militer Tinggi pada Tingkat Pertama:

a. memeriksa dan memutus perkara pidana yang Terdakwanya adalah: 1) Prajurit atau salah satu Prajurit berpangkat Mayor keatas. b. memeriksa, memutus dan menyelesaikan sengketa Tata Usaha Negara.

2. Pengadilan Militer Tinggi memeriksa dan memutus pada tingkat banding perkara pidana yang telah diputus oleh Pengadilan Militer dalam daerah hukumnya dimintakan banding.

UU No 31 Tahun 1997 Peradilan Militer Pasal 42 Tugas dan Wewenang Pengadilan Militer Utama sebagai berikut:

Pasal 42

Pengadilan Militer Utama memeriksa dan memutus pada tingkat banding perkara pidana dan sengketa Tata Usaha Angkatan Bersenjata yang telah diputus pada tingkat pertama oleh Pengadilan Militer Tinggi yang dimintakan banding.

Dalam pembentukan Undang-Undang Peradilan/Pengadilan Militer yaitu UU No 31 Tahun 1997,pembentukannya harus dibentuk oleh Presiden serta disetujui oleh Dewan Perwakilan Rakyat yang tertera dalam Pasal 5 ayat 1 , Pasal 20 ayat 1 UUD 1945 sebagai berikut:

(1) Presiden memegang kekuasaan membentuk undang-undang dengan persetujuan Dewan Perwakilan Rakyat.

(1) Tiap-tiap undang-undang menghendaki persetujuan Dewan Perwakilan Rakyat.

Pembentukan menurut Kamus Besar Bahasa Indonesia mempunyai pengertian proses,perbuatan,cara membentuk ${ }^{2}$. Dan bahwa suatu struktur yang terdapat dalam

2 Fuad Hassan, Pengertian Pembentukan, Balai Pustaka, Jakarta, 1999, hlm. 119. 
lembaga peradilan dapat dibentuk melalui proses yang bertujuan untuk dapat mengisi kekosongan pada struktur organisasi yang terdapat pada lembaga peradilan khususnya peradilan militer serta prajurit TNI menduduki suatu jabatan fungsional atau struktural. ${ }^{3}$ Pembinaan dalam Kamus Besar Bahasa Indonesia adalah Proses,perbuatan usaha,tindakan,merupakan suatu tata cara untukmendidik, melaksanakan sistem administrasi Lembaga Peradilan,sistem tata cara persidangan Lembaga Peradilan yang dilaksanakan oleh para pegawai /atau pejabat yang menduduki jabatan structural maupun fungsional di lembaga peradilan dalam lingkungan peradilan militer.

Fokus Kajian Penelitian ini adalah pembentukan dan pembinaan pengadilan militer pertempuran, pengadilan militer pertempuran merupakan pengadilan militer yang bersifat mobil yang dimana mengikuti gerakan pasukan,pembentukan organisasi pada pengadilan militer pertempuran dibawah kewenangan mahkamah agung republik indonesia yang bersifa relatif yaitu pendelegasian kewenangan, diartikan bahwa delegasi wewenang dari Mahkamah Agung Republik Indonesia ke Pengadilan Militer Utama yang bertujuan untuk pembinaan dalam hal non yuridis dan pembentukan organisasi yang dimana Mahkamah Agung sebelum mendelegasikan wewenang tersebut Mahkamah Agung beserta Panglima TNI membentuk Kelompok Kerja (POKJA),setelah terbentuk Kelompok Kerja maka akan diadakan pembahasan Naskah Akademik pembentukan dan pembinaan pengadilan militer pertempuran, dalam pembahasan naskah akademik tersebut dibahas mengenai pengalihan organisasi dari MABES TNI ke Mahkamah Agung Republik Indonesia yang sesuai pada Kepres Nomor 56 Tahun 2004. Dari hasil pembahasan mengenai Pembentukan dan Pembinaan Pengadilan Militer Pertempuran yaitu nama-nama Prajurit TNI yang terpilih untuk menduduki jabatan structural dan fungsional di Pengadilan Militer Pertempuran maka kewenangan mahkamah agung yang bersifat delegasi tersebut diberikan kepada Pengadilan Militer Utama untuk diberikan pembentukan organisasi yang dimana pembentukan organisasi tersebut diberikan oleh Mahkamah Agung dari hasil pembahasan Naskah Akademik pembentukan dan pembinaan pengadilan militer pertempuran,dan pembinaan secara Non Yuridis yang telah dijelaskan pada penjelasan diatas secara procedural. Setelah dibentuk dan dibina maka selanjutnya dialihkan kepada Mahkamah Agung untuk pengesahan lembaga pengadilan militer pertempuran yang berupa satu atap dengan Pengadilan Militer Utama. Karakteristik Pengadilan Militer Pertempuran yang mobil dan dalam hal pembentukan dan pembinaan pengadilan militer pertempuran mengacu pada Pasal 12,Pasal 45,dan Pasal 46 Undang-undang Nomor 31 Tahun 1997, Keputusan Presiden Nomor 56 Tahun 2004 tentang Pengalihan Organisasi,

3 Fuad Hassan, Pengertian Pembinaan, Balai Pustaka, Jakarta, 1999, hlm. 134. 
Administrasi,dan Finansial dari Markas Besar

Tentara Nasional Indonesia ke Mahkamah

Agung, Pokok-Pokok Organisasi Dan

Prosedur Badan Pelaksana Pusat Angkatan

Bersenjata Republik Indonesia Nomor: P.101080303, Surat Keputusan Bersama Ketua Mahkamah Agung Republik Indonesia Dan Panglima TNI Nomor :KMA /065A/SKB/ IX/2004 Nomor:Skep/420/IX/2004 tentang Kerja Sama Dalam Pembinaan Personel Militer Bagi Prajurit TNI Yang Bertugas Pada Pengadilan Dalam Lingkungan Peradilan Militer,Undang-Undang Dasar Negara Republik Indonesia Tahun 1945 Pasal 24 ayat (1) dan (2), Undang-undang RI Nomor 26 Tahun 1997 tentang Hukum Disiplin Prajurit Angkatan Bersenjata Republik Indonesia, Undang-undang Nomor 04 Tahun 2004 tentang Kekuasaan Kehakiman.Pada latar belakang diatas, maka dapat dirumuskan suatu rumusan masalah sebagai berikut:

a. Mengapa Pengadilan Militer Pertempuran di Indonesia Belum dibentuk oleh Mahkamah Agung RI?

b. Upaya apa yang dilakukan oleh Mahkamah Agung RI dalam rangka pembentukan Pengadilan Militer Pertempuran?

c. Bagaimana pembentukan Pengadilan Militer Pertempuran yang ideal sesuai dengan karakteristik Pengadilan Militer yang Mobil sebagaimana dimaksudkan Pasal 46 Undang-Undang No 31 Tahun $1997 ?$

\section{Pembahasan}

\section{A. Kewenangan Mahkamah Agung} dalam Pembentukan Pengadilan Militer Pertempuran

Pembentukan peradilan dari setiap pelaku kekuasaan kehakiman yang disebut Mahkamah atau Pengadilan dibawahnya memiliki fungsi yang sama yaitu mengadili. Dalam kekuasaan kehakiman,yang dibagi adalah hukum yang menguasai objek sengketa. Pembagian hukum tersebut didasarkan pada bidang atau tingkatan tertentu dalam hierarki hukum.Berdasarkan Pasal 24 ayat (2) UUD 1945 setelah perubahan,secara eksplisit tertera kekuasaan kehakiman dilakukan oleh sebuah Mahkamah Agung dan badan peradilan yang berada dibawahnya dalam lingkungan peradilan umum,lingkungan peradilan agama,lingkungan peradilan militer,lingkungan peradilan tata usaha negara.Lingkungan peradilan militer merupakan kekuasaan kehakiman yang dibawah kewenangan Mahkamah Agung yang terdiri dari:

a. Pengadilan Militer

b. Pengadilan Militer Tinggi

c. Pengadilan Militer Utama

d. Pengadilan Militer Pertempuran

Kewenangan Mahkamah Agung dalam ${ }^{4}$ pembentukan Pengadilan Militer Pertempuran terkait dengan Kerja Sama Antara Mahkamah Agung dengan Panglima TNI. Kewenangan tersebut bersifat Profesional dikarenakan

4 Wawancara dengan Bapak X, Laksamana Pertama TNI-AL, 29 Agustus-2Oktober 2014. 
selama ini Pengadilan Militer Pertempuran masihbelumterbentukstrukturorganisasi,kerja sama yang dilakukan oleh Mahkamah Agung dan Panglima TNI bertujuan untuk membentuk organisasi pengadilan militer pertempuran yang berhasil guna dan berdaya guna,berhasil guna dan berdaya guna ini dapat diartikan sebagai pembentukan organisasi yang menghasilkan prajurit TNI yang professional dalam memeriksa dan memutus perkara pidana militer di daerah pertempuran. menghasilkan prajurit TNI/atau Personel Militer yang professional dapat disediakan oleh Panglima TNI yang mengecheck dari segi latar belakang pendidikan yaitu Sarjana Hukum (Korp Sarjana Hukum), Prajurit TNI adalah Prajurit TNI/atau Personel Militer yang memiliki Pangkat Perwira Menengah dari Angkatan Darat, Angkatan Laut maupun dari Angkatan Udara.

Kewenangan yang terdiri dari beberapa wewenang,yaitu merupakan kekuasaan terhadap segolongan orang tertentu atau kekuasaan terhadap suatu bidang pemerintahan yang berlandaskan peraturan perundangundangan. Kekuasaan Mahkamah Agung yang terdiri dari kewenangan yang bersifat yudikatif dikarenakan Mahkamah Agung adalah badan yudikatif yang sebagai induk dari badan-badan peradilan dibawahnya. Mahkamah Agung yang bekerja sama dengan Panglima TNI memiliki suatu kewenangan di dalam Undang-Undang terutama dalam Surat Keputusan Bersama Ketua Mahkamah Agung Republik Indonesia dan Panglima TNI
Nomor: KMA/065A/SKB/IX/2004 Nomor:

Skep/420/IX/2004 tentang Kerja Sama Dalam Pembinaan Personel MiliterBagi Prajurit TNI Yang Bertugas Pada Pengadila Dalam Lingkungan Peradilan Militer.Yang tertera pada:

Pasal 4

Kebutuhan prajurit untuk menduduki jabatan structural dan/atau fungsional pada pengadilan dalam lingkungan Peradilan Militer disediakan oleh Mabes TNI atas Permintaan Mahkamah Agung.

Pasal 5

Prajurit yang menduduki jabatan structural dan/atau jabatan fungsional pada Pengadilan dalam lingkungan Peradilan Militer berstatus sebagai prajurit Aktif

Pembentukan Pengadilan Militer Pertempuran pada hal ini adalah Pembentukan Organisasi, sebelum dibentuk organisasi pengadilan militer pertempuran maka terdapat Pengalihan Organisasi,Administrasi,dan Finansial Pengadilan dalam Lingkungan Peradilan Militer dari Markas Besar Tentara Nasional Indonesia ke Mahkamah Agung. Pengalihan Organisasi, Administrasi dan Finansial bertujuan Kewenangan Mahkamah Agung bersifat penuh tercantum pada Keputusan Presiden Nomot 56 Tahun 2004:

Pasal 2 Ayat

(1) Organnisasi, administrasi dan financial pada Pengadilan dalam lingkungan peradilan militer dialihkan dari Markas 
Besar Tentara Nasional Indonesia ke Mahkamah Agung terhitung sejak tanggal 30 Juni 2004

(2) Sejak pengalihan sebagaimana dimaksud dalam ayat (1),pembinaan organisasi,administrasi,dan financial pengadilan dalam lingkungan peradilan militer berada di Mahkamah Agung.

Pasal 3

Sejak dialihkannya organisasi, adminitrasi,dan financial pada pengadilan dalam lingkungan Peradilan Militer sebagaiaman dimaksud dalam Pasal 2, semua Pegawai Negeri Sipil pada pengadilan dalam lingkungan Peradilan Militer beralih menjadi Pegawai Negeri Sipil pada Mahkamah Agung.

Pasal 4 Ayat

(1) Semua aset milik/barang inventaris yang digunakan oleh pengadilan dalam lingkungan Peradilan Militer tidak dialihkan kepada Mahkamah Agung

(2) Pengadaan barang/inventaris yang akan digunakan oleh pengadilan dalam lingkungan Peradilan Militer menjadi beban dan tanggung jawab Mahkamah Agung.

(3) Sebelum sarana dan prasarana disediakan oleh Mahkamah Agung, pengadilan dalam lingkungan Peradilan Militer masih tetap menggunakan sarana dan prasarana Markas Besar Tentara Nasional Indonesia.

(4) Biaya pemeliharaan atas penggunaan sarana dan prasarana sebagaimana dimaksud dalam ayat (3), dibebankan pada anggaran Mahkamah Agung.

\section{Pasal 5 Ayat}

(1) Untuk kelancaran pengalihan Organisasi, administrasi dan financial pada pengadilan dalam lingkungan peradilan militer sebagaimana dimaksud dalam Pasal 2, dibentuk Tim Pengalihan dan Penataan Kelembagaan, Kepegawaian, Keuangan, Arsip dan Dokumentasi

(2) Tim Pengalihan dan penataan sebagaimana dimaksud dalam ayat(1) terdiri dari Unsur Mahkamah Agung, Markas Besar Tentara Nasional Indonesia,Kantor Menteri Negara Pendayagunaan Aparatur Negara,Badan Kepegawaian Negara, Departemen Keuangan,dan Arsip Nasional Republik Indonesia yang dibentuk dengan Keputusan Mahkamah Agung.

(3) Tim Pengalihan dan Penataan sebagaimana dimaksud dalam ayat(1) dan ayat (2) bertugas:

a. mengalihkan kelembagaan, kepegawaian, keuangan, arsip, dan dokumentasi dari Markas Besar Tentara Nasional Indonesia ke Mahkamah Agung.

b. menata kelembagaan, kepegawaian, keuangan, arsip dan dokumentasi disesuaikan dengan kewenangan dan beban tugas Mahkamah Agung.

Pasal 6 Ayat

(1) Tim sebagaimana dimaksud dalam Pasal 5 terdiri dari:

a. Bidang Kelembagaan dipimpin oleh Deputi Menteri Negara 
Pendayagunaan Aparatur Negara Bidang Kelembagaan

b. Bidang Kepegawaian dipimpin oleh Kepala Badan Kepegawaian Negara

c. Bidang Keuangan dipimpin oleh Direktur Jendral Anggaran Departemen Keuangan

d. Bidang Arsip dan Dokumentasi dipimpin oleh Kepala Arsip Nasional Republik Indonesia

(2) Dalam melaksanakan tugasnya, Tim berkoordinasi dengan Sekretaris Jendral Mahkamah Agung.

Setelah Pengalihan Organisasi tersebut dilaksanakan atau telah berpindah maka Mahkamah Agung berkoordinasi dengan Kepala Pengadilan Militer Utama (KADIMILTAMA) untuk bersedia menjadi satu payung atau satu atap lembaga di Pengadilan Militer Utama tetapi beda stuktur organisasi,beda strukutur organisasi memang ada perbedaan mengingat Pengadilan militer pertempuran bersifat mobile tercantum pada Pasal 46 Undang-Undang Nomor 31 tahun 1997. Perbedaan struktur organisasi yang dijabat oleh Personel TNI nantinya akan dibawah komando dari pengadilan militer utama mengingat bahwa Pengadilan Militer Pertempuran merupakan pengadilan militer yang memeriksa dan memutus perkara pidana militer pada tingkat pertama dan terakhir.Serta Personel Militer yang dipilih /atau disediakan oleh Panglima TNI tersebut harus berpangkat Perwira Menengah Atas dan Berlatar Belakang Sarjana Hukum (Korps Hukum).

Pertimbangan Kewenangan Mahkamah Agung dalam pembentukan pengadilan militer aspek lain,dijelaskan sebagai berikut:

B. Efektifitas Mahkamah Pembinaan Pengadilan Militer Pertempuran

Efektifitas hukum berfungsi bahwa sejauh mana suatu aturan hukum tersebut ditaati atau tidak ditaati, jika suatu aturan hukum ditaati oleh sebagian besar target yang menjadi sasaran ketaatannya,aturan hukum yang bersangkutan adalah efektif. Relevansi aturan hukum pada Undang-Undang Nomor 31 Tahun 1997 sebagian telah relevan sehingga pembentukan dan pembinaan pengadilan militer, pengadilan militer tinggi,pengadilan militer utama telah terlaksana, tetapi pada Pengadilan militer pertempuran Relevansi tersebut akan dilaksanakan pada Pasal 46 Undang-undang Nomor 31 Tahun 1997 tentang Peradilan Militer tersebut mudah dipahami. Walupun Pengadilan Militer Pertempuran bersifat Mobil atau mengikuti gerakan pasukan, Relevansi terhadap pemahaman aturan hukum-hukum yang ada tertuju pada efektifitas, antara lain:

Pasal 3

Pendidikan profesi dan pembinaan kemampuan teknis yudisial Hakim dan Panitera pada pengadilan dalam lingkungan Peradilan Militer dilaksanakan oleh Mahkamah Agung.

Pasal 4

Kebutuhan prajurit untuk menduduki jabatan structural dan/atau jabatan fungsional pada 
Pengadilan dalam lingkungan Peradilan Militer disediakan oleh Mabes TNI atas permintaan Mahkamah Agung.

Pasal 5

Prajurit yang menduduki jabatan structural dan/atau jabatan fungsional pada Pengadilan dalam lingkungan Peradilan Militer berstatus sebagai prajurit aktif.

Pasal-Pasal dijelaskan diatas memilik Dasar Hukum tercantum pada Surat Keputusan Bersama Ketua Mahkamah Agung Dan Panglima TNI Nomor: KMA/065A/SKB/ IX/2004 Nomor: Skep/420/IX/2004 tentang Kerja Sama Dalam Pembinaan Personel Militer Bagi Prajurit TNI Yang Bertugas Pada Pengadilan Dalam Lingkungan Peradilan Militer. Pembinaan dapat dilaksanakan oleh Mahkamah Agung yang berkoordinasi dengan Pengadilan militer utama. Koordinasi pembinaan pengadilan militer pertempuran yang dimana kewenangan tersebut yang berupa pendelegasian kewenangan,Pendelagasian Kewenangan kepadaPengadilan Militer Utama memiliki Dasar Hukum sebagai pengguat argumentasi pendelagisan kewenangan yaitu pada Undang-Undang Nomor 31 Tahun 1997 berupa:

Pasal 44 Ayat

(1). Pengadilan Militer Utama melakukan pengawasan terhadap:

a. Penyelenggaraan peradilan di semua lingkungan Pengadilan Militer, Pengadilan Militer Tinggi,Pengadilan Militer Pertempuran di daerah hukumnya masing-masing b. Tingkah Laku dan perbuatan para hakim dalam menjalankan tugasnya

(2). Pengadilan Militer Utama berwenang untuk meminta keterangan tentang hal-hal yang bersangkutan dengan teknis peradilan dari Pengadilan Militer, Pengadilan Militer Tinggi dan Pengadilan Militer Pertempuran.

(3). Pengadilan Militer Utama memberi petunjuk, teguran, atau peringatan yang dipandang perlu kepada Pengadilan Militer,Pengadilan Militer Tinggi dan Pengadilan Militer Pertempuran.

(4). Pengawasan dan Kewenangan sebagaimana dimaksud pada ayat (1), ayat (2), dan ayat(3) tidak mengurangi kebebasan hakim dalam memeriksa dan memutus perkara.

Pada Penjelasan pasal-pasal diatas yang tercantum pada Undang-undang Nomor 31 Tahun 1997, maka dengan itu Teknis Peradilan dan Petunjuk yang dilakukan oleh Pengadilan Militer Utama kepada Pengadilan Militer dibawahnya, berupa:

a. Pembinaan Teknis Yudisial Bagi Hakim Militer Pertempuran

1. Teknis pelaksanaan persidangan daerah pertempuran

2. Teknis pembuatan keputusan perkara persidangan pertempuran

b. Pembinaan Teknis Yudisial Bagi Panitera Militer Pertempuran

1. Pembuatan Berita Acara Persidangan Pertempuran

2. Pembinaan Bidang Finansial meliputi: 
a. Pemberian tunjangan kepada pejabat hakim militer pertempuran

b. Pemberian Remunrasi bagi pegawai negeri dan Panitera serta Pembinaan Bidang Keuangan di struktur organisasi pengadilan militer pertempuran

c. Pembinaan Sarana meliputi:

1. Penyediaan Pakaian Dinas Lapangan (Doreng) bagi Hakim Militer Pertempuran

2. Penyediaan Kantor Darurat/atau Tenda di Kawasan Pertempuran

3. Penyediaan Senjata Api jika diperlukan dalam Keadaan Bahaya (Warning Condition)

4. Penyediaan pesawat terbang dinas menuju ke daerah pertempuran.

Dari Hasil Pendelagisan Kewenangan dari Mahkamah Agung ke Pengadilan Militer Utama, maka Kewenangan tersebut kembali kepada Mahkamah Agung RI untuk dilaksanakan Pengesahan dari Hasil Pembinaan Personel Pengadilan Militer Pertempuran pada Pengadilan Militer Utama.

\section{Upaya Mahkamah Agung dalam pembentukan dan pembinaan Pengadilan Militer Pertempuran}

Upaya pembentukan organisasi pengadilan militer pertempuran salah satunya adalah menyusun kelompok kerja di Mahkamah Agung bidang Kemiliteran yang bertujuan untuk menganalisis Naskah Akademik prosedur pembentukan organisasi pengadilan militer pertempuran. Pembinaan
Kerja Sama Karier bertujuan menciptakan Personel Militer yang bertanggung jawab dan profesional,menurut Peraturan PerundangUndangan yang berlaku, pada Surat Keputusan Bersama Ketua Mahkamah Agung dan Panglima TNI Nomor: KMA/065A/ SKB/IX/2004 dan Nomor: Skep/420/IX/2004 tentang Kerja Sama Dalam Pembinaan Personel Militer Bagi Prajurit TNI Yang Bertugas Pada Pengadilan Dalam Lingkungan Peradilan Militer.Pembinaan Kerja Sama Bidang Karir harus bersifat transparansi tercantum pada:

Pasal 4

Kebutuhan prajurit untuk menduduki jabatan structural dan/atau fungsional pada pengadilan dalam lingkungan Peradilan Militer disediakan oleh Mabes TNI atas permintaan Mahkamah Agung.

Pasal 5

Prajurit yang menduduki jabatan structural dan/atau fungsional pada Pengadilan dalam lingkungan Peradilan Militer berstatus sebagai prajurit aktif. Disiplin Prajurit Angkatan Bersenjata Republik Indonesia adalah ketaatan dan Kepatuhan yang sungguh-sungguh setiap prajurit Angkatan Bersenjata Republik Indonesia yang didukung kesadaran yang bersendikan Sapta Marga dan Sumpah Prajurit untuk menunaikan tugas dan kewajiban serta bersikap dan berperilaku sesuai dengan aturan-aturan atau tata kehidupan Prajurit Angkatan Bersenjata Republik Indonesia.Pembinaan Hukum Disiplin Prajurit mematuhi pada Peraturan 
Undang-Undang Nomor 26 Tahun 1997 tentang Hukum Disiplin Prajurit Angkatan Bersenjata,dilaksanakan oleh Panglima TNI kepada Prajurit TNI yang didalam pembinaan tersebut berisi:
a. Disiplin Prajurit
b. Pelanggaran Hukum Disiplin Prajurit
c. Tindakan Disiplin
d. Hukuman Disiplin

Pembinaan Hukum Disiplin Prajurit digunakanagarPrajuritTNIselalumenjalankan tugas dan kewajiban sesuai Sapta Marga dan Sumpah Prajurit sebelum Prajurit TNI/ atau Personel Militer tersebut diangkat serta menduduki jabatan structural dan fungsional di Pengadilan Militer Pertempuran.

\section{Pembinaan}

Pendidikan

\section{Pengembangan dan Profesi}

\section{Personel Militer Pengadilan Militer Pertempuran}

Pembinaan Pendidikan Pengembangan Umum dan Spesialisasi Keprajuritan yang dilaksanakan oleh Panglima TNI dalam Pembinaan Personel TNI pada struktur organisasi Pengadilan Militer Pertempuran memiliki Dasar Hukum Surat Keputusan Bersama Ketua Mahkamah Agung Republik Indonesia dan Panglima TNI Nomor: KMA/065A/SKB/IX/2004 Nomor :

Skep/420/IX/2004 tentang Kerja Sama Dalam Pembinaan Personel Militer Bagi Prajurit TNI Yang Bertugas Pada Pengadilan Dalam Lingkungan Peradilan Militer sesuai dengan:

Pasal 2

Pendidikan Pengembangan umum dan
Pendidikan Pengembangan Spesialisasi Keprajuritan dilaksanakan oleh Markas Besar Tentara Nasional Indonesia yang selanjutnya disingkat Mabes TNI setelah dikoordinasikan dengan Mahkamah Agung.

Dalam Pasal 2 diatas penguraian penjelasan meliputi:

1. Bisa berpikir secara cerdas pada saat situasi darurat pelaksanaan persidangan di daerah pertempuran jika Personel Militer tersebut merupakan Majelis Hakim dan Panitera

2. Memberikan Gambaran-Gambaran situasi di daerah pertempuran

3. Memberikan Pendidikan Pelatihan Tembak jika situasi darurat yang bertujuan sebagai pertahanan diri bagi Hakim Militer dan Panitera.

Pada Penjelasan Undang-Undang Nonor 31 Tahun 1997 tentang Peradilan Militer, tercantum pada Pasal 6 bahwa Pembinaan teknis pengadilan dalam lingkungan peradilan militer dilakukan oleh Mahkamah Agung,jika dikembangkan lebih spesifik maka Pengembangan Pasal 6 tersebut harus dikembangkan pada Surat Keputusan Bersama Ketua Mahkamah Agung Dan Panglima TNI Nomor :KMA/065A/SKB/ IX/2004 Nomor :Skep/420/IX/2004 tentang Kerja Sama Dalam Pembinaan Personel Militer Bagi Prajurit TNI Yang Bertugas Pada Pengadilan Dalam Lingkungan Peradilan Militer,yang terdiri atas:

1. Pembinaan Pendidikan Profesi Hakim dan Panitera Pengadilan Militer Pertempuran 
Pasal 3

Pendidikan profesi dan pembinaan kemampuan teknis yudisial dan Panitera pada pengadilan dalam lingkungan Peradilan Militer dilaksanakan oleh Mahkamah Agung

Pendidikan profesi merupakan pendidikan yang dilaksanakan oleh Mahkamah Agung dalam mendidik para Hakim-Hakim Militer yang diangkat dan dipilih untuk diberikan pendidikan profesi yang berupa menegakkan selalu dan berpegang pada prinsip Azaz-Azaz Kekuasaan Kehakiman.Pendidikan profesi tersebut tercantum dalam Undang-Undang Nomor 48 Tahun 2009 tentang Kekuasaan Kehakiman:

Pasal 2 Ayat

(1).Peradilan dilakukan "DEMI KEADILAN BERDASARKAN KETUHANAN YANG MAHA ESA."

(2) Peradilan negara menerapkan dan menegakkan hukum dan keadilan berdasarkan Pancasila

(3) Semua peradilan diseluruh wilayah negara Republik Indonesia adalah peradilan negara yang diatur oleh undang-undang

(4) Peradilan dilakukan dengan sederhana,cepat,dan biaya ringan

Pembinaan Teknis Yudisial Hakim dan Panitera Pengadilan Militer Pertempuran Pada penjelasan diatas telah dijelaskan bawah Pembinaan Teknis Yudisial Hakim dan Panitera Pengadilan Militer Pertempuran
Kewenangan Mahkamah Agung dapat di delegasikan ke Pengadilan Militer Pertempuran dengan meliputi :

a. Pembinaan Teknis Yudisial Bagi Hakim Militer Pertempuran

1. Teknis pelaksanaan persidangan daerah pertempuran

2. Teknis pembuatan keputusan perkara persidangan pertempuran

b. Pembinaan Teknis Yudisial Bagi Panitera Militer Pertempuran

1. Pembuatan Berita Acara Persidangan Pertempuran

2. Pembinaan Bidang Finansial meliputi:

a. Pemberian tunjangan kepada pejabat hakim militer pertempuran

b. Pemberian Remunrasi bagi pegawai negeri dan Panitera serta Pembinaan Bidang Keuangan di struktur organisasi pengadilan militer pertempuran

c. Pembinaan Sarana meliputi :

1. Penyediaan Pakaian Dinas Lapangan (Doreng) bagi Hakim Militer Pertempuran

2. Penyediaan Kantor Darurat/ atau Tenda di Kawasan Pertempuran

3. Penyediaan Senjata Api jika diperlukan dalam Keadaan Bahaya (Warning Condition)

4. Penyediaan pesawat terbang dinas menuju ke daerah pertempuran. 
Pembinan Mutasi atau sering disebut Pemutasian menurut Kamus Besar Bahasa Indonesia adalah Pemindahan pegawai dari satu jabatan ke jabatan lain.Pelaksanaan Mutasi bagi Hakim Militer Pertempuran bersifat Transparansi, meliputi:

1. Kenaikkan Pangkat serta meningkatkan kemampuan profesi yang baik sebagai penyelenggara kekuasaan kehakiman dan memiliki integritas moral yang prima dari Hakim Militer Biasa ke Hakim Militer Pertempuran

2. Dapat terselenggaranya dukungan administrasi yang memadai,baik administrasi personel maupun perkara

3. Terwujudnya pengadilan dalam lingkungan Peradilan Militer yang mampu melaksanakan tugas dan fungsinya dengan baik.

4. Membentuk instink dan naluri hakim yang baik,hal ini diperlukan dalam rangka memberikan dan meningkatkan pelayanan pengadilan dilingkungan Peradilan Militer khususnya Pengadilan Militer Pertempuran.

Pada Penjelasan diatas mengenai pembinaan mutasi hakim militer memiliki Dasar Hukum yang digunakan untuk memperkuat argumentasi. Dasar Hukum tersebut Surat Keputusan Bersama Ketua Mahkamah Agung dan Panglima TNI Nomor: KMA/065A/SKB/IX/2004 dan Nomor: Skep/420/IX/2004 tentang Kerja Sama Dalam Pembinaan Personel Militer Bagi Prajurit TNI Yang Bertugas Pada Pengadilan Dalam
Lingkungan Peradilan Militer,tercantum pada: Pasal 6 Ayat

(1).Pengangkatan dalam dan pemberhentian dan jabatan structural bagi prajurit yang bertugas pada pengadilan dalam lingkungan peradilan militer ditetapkan dengan Surat Keputusan Panglima TNI atas usul Ketua Mahkamah Agung dan/atau atas pertimbangan Mabes TNI

(2).Setelah Panglima TNI mengeluarkan Surat Keputusan tentang Pengangkatan dalam dan pemberhentian dari jabatan sebagaimana dimaksud pada ayat(1) selanjutnya pelaksanaannya ditetapkan dengan Surat Keputusan Ketua Mahkamah Agung.

Pasal 7

Kenaikan pangkat bagi prajurit yang bertugas pada pengadilan dalam lingkungan peradilan militer diproses dan/atau ditentukan oleh Mabes TNI atas usul Mahkamah Agung dan/ atau atas pertimbangan Mabes TNI.

Pembentukan Karakteristik Pengadilan Militer Pertempuran yang ideal merupakan pembentukan organisasi yang sesuai Pasal 46 Undang-Undang Nomor 31 Tahun 1997. Mengingat Pengadilan Militer Pertempuran yang bersifat mobil mengikuti gerakan pasukan,maka pembentukan organisasi dapat dilakukan oleh Mahkamah Agung serta dibawah payung/atau satu lembaga Pengadilan Militer Utama tetapi beda organisasi dan pelaksanaannya. Karakteristik Pengadilan Militer Pertempuran yang ideal, meliputi: Pengadilan Militeryang siap digerakkan bahwa mengingat pengadilan militer pertempuran 
yang bersifat mobil mengikuti gerakan pasukan, maka pembentukan organisasi pengadilan militer pertempuran dapat dibentuk sebelum ada pertempuran,dibentuknya organisasi pengadilan militer pertempuran tersebut bertujuaan untuk mengantisipasi kemungkinan akan terjadi perang yang tidak tahu kapan pertempuran tersebut terjadi dan siap digerakkan disini Para Hakim-Hakim Militer dan Panitera yang telah terdidik professional dalam memeriksa dan memutus perkara pidana militer di daerah pertempuran. Dasar Hukum untuk menguatkan argumentasi diatas Undang-Undang Nomor 31 Tahun 1997 tentang Peradilan Militer

Pasal 45

Pengadilan Militer pertempuran memeriksa dan memutus pada tingkat pertama dan terakhir perkara pidana yang dilakukan oleh mereka sebagaimana dimaksud dalam Pasal 9 angka 1 di daerah pertempuran

Pasal 46

Pengadilan Militer Pertempuran bersifat mobil mengikuti gerakan pasukan dan berkedudukan serta berdaerah hukum di daerah pertempuran Susunan Majelis Hakim pada Pengadilan Militer Pertempuran merupakan susunan MajelisHakimyang dimanabelum diaturdalam peraturan perundang-undangan,sebaiknya pertimbangan dalam mengatur susunan majelis hakim pengadilan militer pertempuran harus melalui Kepres yang berisi tentang Susunan Majelis Hakim Pengadilan Militer Pertempuran dikarenakan dasar hukum melalui Kepres lebih menguatkan peraturan perundang-undangan tersebut.Sedangkan Susunan Majelis Hakim tidak Hakim Tunggal dikarenakan untuk menjaga objektifitas dalam memeriksa perkara pidana militer pertempuran. Pakaian Dinas pada Pengadilan Militer Pertempuran memang sangat diperlukan dalam persidangan pertempuran pada pengadilan militer pertempuran,sama dengan penjelasan diatas aturan mengenai Pakaian dinas pada persidangan pertempuran belum diatur,sebaiknya pakaian dinas diatur melalui Kepres dan menjadi satu bagian aturan dengan Majelis Hakim pada Pengadilan Militer Pertempuran.Pakaian Dinas sidang yang pantas dikenakan oleh Majelis Hakim adalah Pakaian dinas sidang Doreng dikarenakan sesuai dengan daerah pertempuran.

\section{Simpulan}

$\begin{array}{rrr}\text { Berdasarkan } & \text { Penelitian yang } \\ \text { dilakukan oleh } & \text { Peneliti,maka dapat }\end{array}$ disimpulkan bahwa: Pengadilan Militer Pertempuran belum dibentuk dikarenakan belum dialihkannya organisasi,administrasi dan finansial pengadilan dalam lingkungan peradilan militer dari Markas Besar TNI (MABES TNI) ke Mahkamah Agung RI serta belum terbentuknya struktur organisasi lembaga pengadilan militer pertempuran menjadi Kewajiban Mahkamah Agung RI. Upaya yang dilakukan oleh Mahkamah Agung dalam pembentukan dan pembinaan pengadilan militer pertempuran: Mahkamah Agung dan Panglima TNI bekerja sama dalam 
hal menyusun Kelompok Kerja(POKJA) yang disusun dari Mahkamah Agung yang bertujuan untuk membahas Naskah Akademik pembentukan dan pembinaan pengadilan militer pertempuran dan Pembinaan personel aktif dilakukan oleh Mahkamah Agung dan Markas Besar TNI. Pembentukan Pengadilan Militer Pertempuran ideal antara lain: Susunan Majelis Hakim Pengadilan Militer Pertempuran berbeda dengan Pengadilan
Militer biasa, artinya di pengadilan militer biasa susunan majelis hakim minimal 3(tiga) orang, lalu untuk untuk pengadilan militer pertempuran cukup hakim tunggal (satu orang hakim), Pakaian Dinas Pengadilan Militer Pertempuran adalah Pakaian Dinas Doreng (Pakaian Dinas Lapangan), artinya disesuaikan dengan medan tugasnya di daerah pertempuran.

\section{DAFTAR PUSTAKA}

\section{Buku}

Ahcmad Ali, 2009, Menguak Teori Hukum dan Teori Peradilan, Faktor-faktor yang Mempengaruhi Ketaatan terhadap Hukum Secara Umum, Kencana Prenada Media Group, Jakarta.

Ahmad Fadlil Sumadi, 2013, Pengawasan dan Pembinaan Pengadilan, Sejarah Perkembangan Mahkamah Agung, Setara Press, Malang

AhmadFadlil Sumadi, 2013, Pengawasan dan

Pembinaan Pengadilan, Pengadilan di bawah Mahkamah Agung, Setara Press, Malang.

Ahmad Fadlil Sumadi, 2013, Pengawasan dan Pembinaan Pengadilan, Setara Press, Malang.

Moch. Faisal Salam, 1994, Peradilan Militer

Indonesia, Mandar Maju, Bandung.

Safri Nugraha, 2007, Pengantar Pengertian

Kewenangan, Hak, Kewajiban dan

Tanggung Jawab Administrator, Center For Law and Good Governance Studies (CLGS), Depok.

Safri Nugraha, 2007, Hukum Administrasi Negara (Edisi Revisi), Pengertian Wewenang, Center For Law And Good Governance Studies (CLGS), Depok.

\section{Peraturan Perundang-undangan}

Undang-Undang Dasar Negara Republik Indonesia Tahun 1945.

Undang-undang tentang Peradilan Militer UU Nomor 31 Tahun 1997 Lembaran Negara Republik Indonesia Nomor 3713.

Undang-undang tentang Kekuasaan Kehakiman UU Nomor 48 Tahun 2009. Lembaran Negara Republik Indonesia Tahun 2009 Nomor 157 Tambahan Lembaran Negara Nomor 5076. 
Surat Keputusan Bersama Ketua Mahkamah

Agung RI dan Panglima TNI Nomor:

KMA/065A/SKB/IX/2004 Nomor:

Skep/420/IX/2004 tentang Kerja Sama

Dalam Pembinaan Personel Militer

Bagi Prajurit TNI Yang Bertugas

Pada Pengadilan Dalam Lingkungan

Peradilan Militer.

Surat Keputusan Bersama Ketua Mahkamah

Agung dan Panglima TNI Nomor:

K M A / 065 A / S K B / I X / 2004

Nomor: Skep/421/IX/2004 tentang

Penggunaan dan Perawatan Aset

dan Barang Inventaris Markas

Besar Tentara Nasional Indonesia

oleh Pengadilan Dalam Lingkungan

Peradilan Militer.

Surat Keputusan Panglima Angkatan

Bersenjata Nomor: Kep/01/P/1/1984

Sub Lampiran V dari Lampiran K

Keputusan Pangab tentang Pokok-

pokok Organisasi dan Prosedur

Babinkum ABRI.

\section{Naskah Internet}

Dilmiltama, Sejarah Pengadilan Militer, http://www.dilmiltama.go.id.

Mahkamah Agung Republik Indonesia, Sejarah Mahkamah Agung, https:// www.mahkamahagung.go.id.

Nico Oviten, Kedudukan Hukum Surat Permohonan Keringanan Pidana Oleh Ankum dalam Peradilan Militer, http://hukum.studentjournal. ub.ac.id/index.php/hukum/article/ view/474/469.

\section{Kamus}

Fuad Hassan, 1999, Kamus Besar Bahasa Indonesia, Pengertian Kewenangan, Balai Pustaka, Jakarta.

Fuad Hassan, 1999, Kamus Besar Bahasa Indonesia, Pengertian Pembentukan, Balai Pustaka, Jakarta.

Fuad Hassan, 1999, Kamus Besar Bahasa Indonesia, Pengertian Pembinaan, Balai Pustaka, Jakarta. 